\title{
Burkitt's lymphoma: differential killing of Epstein-Barr virus (EBV) $(+)$ and EBV(-) Burkitt lymphoma cells in vitro and dose-dependent lytic induction by bortezomib in vivo
}

\author{
AL Dufresne*, D Fu and RF Ambinder
}

Address: Department of Oncology, Sidney Kimmel Comprehensive Cancer Center, Johns Hopkins Medical Institutions, Baltimore, Maryland, USA

* Corresponding author

from II th International Conference on Malignancies in AIDS and Other Acquired Immunodeficiencies (ICMAOI): Basic, Epidemiologic, and Clinical

Research

Bethesda, MD, USA. 6-7 October 2008

Published: 17 June 2009

Infectious Agents and Cancer 2009, 4(Suppl 2):PI6 doi:I0.II86/I750-9378-4-S2-PI6

This abstract is available from: http://www.infectagentscancer.com/content/4/S2/PI6

(c) 2009 Dufresne et al; licensee BioMed Central Ltd.

Bortezomib shows in vitro activity against a variety of lymphoid malignancies. It also is known to induce lytic cycle gene expression in several EBV associated malignancies. We compared its activity in killing isogenic $\operatorname{EBV}(+)$ and EBV(-) Akata cells, two Burkitt's lymphoma cell lines, to assess whether activation of viral lytic gene expression might augment killing achieved in the absence of virus.

Cells were treated with bortezomib, ranging in concentration from $10 \mathrm{nM}$ to $300 \mathrm{nM}$, for durations of 2, 24, 48, and 96 hours. Cell viability was determined by trypan blue exclusion, and changes in cell viability were characterized by comparison to untreated Akata cells cultured in parallel. The changes in cell viability resulting from the presence of bortezomib were dose and time dependent. Whereas low doses of bortezomib showed parallel killing effects on $\mathrm{EBV}(+)$ and $\mathrm{EBV}(-)$ tumor cells, higher doses appeared to be more toxic to $\operatorname{EBV}(+)$ cells. These higher doses were associated with a rapid increase in viral DNA copy number. In a murine xenograft model, we assessed activation of lytic infection measured as a function of the ability to concentrate [125I]FIAU. Uptake of [125I]FIAU increased with increasing bortezomib dose in the range of $0.5-2.0 \mu \mathrm{g} / \mathrm{g}$ body mass at 30 hours post bortezomib treatment. These findings are consistent with a doseresponse relationship for bortezomib and EBV lytic infection in $\operatorname{EBV}(+)$ Burkitt's lymphoma cell 